\title{
Vivid Action of Simhanada Guggulu in the Management of Amavata (Rheumatoid Arthritis): A Review
}

\author{
Mishra Meenu ${ }^{1}$, Sharma Chetan ${ }^{2}$, Sharma Shraddha ${ }^{3}$, Shivhare Shwetal ${ }^{4}$ \\ ${ }^{1}$ Post Graduate Scholar Kayachikitsa, ${ }^{2}$ Post Graduate Scholar Samhita Siddhant, \\ ${ }^{3}$ Lecturer Department of Kayachikitsa, ${ }^{4}$ Reader Department of Kayachikitsa, \\ Pt. Khushilal Sharma Govt.(Auto.) Ayurveda College and Institute, Bhopal, Madhya Pradesh, India
}

Corresponding Author: Mishra Meenu

\begin{abstract}
Introduction: Rheumatoid Arthritis is a common form of inflammatory arthritis, occurring throughout the world and in all ethnic groups and affects approximately $1 \%$ of the population worldwide. In Ayurveda Amavata has a high resemblance to Rheumatoid Arthritis. Acharya Madhavakar was the first to give a detailed description of Amavata. Modern treatment of Rheumatoid Arthritis is not satisfactory therefore Ayurvedic medicines are the need of the hour.

Aim \& Objectives: To explore the mode of action of Simhanada Guggulu and to aware about medicinal properties and encourage the use of Simhanada Guggulu in the management of Amavata (Rheumatoid Arthritis).

Materials and Methods: For this study Ayurveda Samhitas, authentic publications, internet and modern medical literature have been reviewed.

Conclusion: The Simhanada Guggulu is Kaphavatahara, Pittavardhaka, Agnideepaka and Amapachaka. The contents of Simhanada Guggulu may act as Disease Modifying Anti Rheumatic Drugs (DMARDS). So it is concluded that Simhanada Guggulu can be used as an effective Ayurvedic medicine for Amavata (Rheumatoid Arthritis).
\end{abstract}

Keywords: Simhanada Guggulu, Rheumatoid Arthritis, Amavata.

\section{INTRODUCTION}

Rheumatoid arthritis is the second most common joint disorder. It is difficult to treat due to its chronicity, incurability, morbidity and complications. The prevalence of RA is approximately 0.8 to $1 \%$ in Europe and Indian subcontinent, with a female to male ratio $3: 1 .{ }^{1}$ Despite the available of best modern drugs the disease has tendency to progress and cripples the patients. In Ayurveda Amavata has a high resemblance to Rheumatoid arthritis. Amavata as a separate disease is not described in Brihatrayi. First time its detailed description is available in medieval period text Madhava Nidana. Viruddhahara (Unwholesome Diet), Viruddhacheshta
(Erroneous Habits), Mandangni(Diminished Agni), Nishchalata (Sedentary Life) and exertion immediately after taking Snigdha Ahara are main causative factors for disease Amavata. Angamarda (myalgia), Aruchi (anorexia), Trishna (thirst), Alasya (laziness), Gourava (heaviness), Jwara (fever), Apaka (indigestion), Angashunata (oedema) are sign and symptoms described by Madhavkar. ${ }^{2}$ RA affect the quality of life of individuals, availability of many advances the modern management (NSAIDS, DMARDS etc.) is not satisfactory. In this review paper a holistic approach is to evaluated the mode of action of Simhanada Guggulu in the management of Amavata (Rheumatoid Arthritis) to aware 
Mishra Meenu et.al. Vivid action of simhanada guggulu in the management of amavata (rheumatoid arthritis): a review.

about medicinal properties and encourage the use of this drug.

\section{AIM AND OBJECTIVES}

1. To explore the mode of action of Simhanada Guggulu in the management of Amavata (Rheumatoid Arthritis).

2. To aware about medicinal properties and encourage the use of Simhanada Guggulu in the management of Amavata (Rheumatoid Arthritis).

\section{MATERIALS AND METHODS}

For this study Ayurveda Samhitas, authentic publications, internet and modern medical literature have been reviewed.

\section{DRUG REVIEW}

Classical reference of Simhanada Guggulu is mentioned in Amavata Prakaran of Bhaishajyaratnavali. ${ }^{3}$

Table No.-1: INGREDIENTS OF SIMHANADA GUGGULU

\begin{tabular}{|l|l|l|l|l|}
\hline S. No. & Drug & English/Botanical Name & Quantity & Parts used \\
\hline 2. & Shuddha Gandhaka & Purified Sulphur & 1 part & - \\
\hline 3. & Amalaki & Emblica officinalis & 1 part & Phala (fruit) \\
\hline 4. & Haritaki & Terminalia Chebula & 1 part & Phala (fruit) \\
\hline 5. & Bhibitaki & Terminalia Bellirica & 1 part & Phala (fruit) \\
\hline 6. & Shuddha Guggulu & Purified Commiphora Mukul & 1 part & Gum resin \\
\hline 7. & Eranda & Ricinus communis & 1 part & Oil \\
\hline
\end{tabular}

\section{METHOD OF PREPARATION}

Get the materials in the above measures. First of all Triphala decoction is prepared, added with castor oil, further heated and then it is added with purified Gandhaka and Guggulu, rolled into pills. Prepare pills in doses of 500mg each.

\section{INDICATIONS}

Amavata (Rheumatoid Arthritis), Vatarakta (Gout), Sandhivata (Osteoarthritis), Kushta (Skin Diseases) and Udara Roga (Diseases of abdomen) etc.

\section{METHOD OF ADMINISTRATION}

Consume pills of $500 \mathrm{mg}$ to $6 \mathrm{gm}$ (as advised by physician) in divided doses such as twice or thrice a day with lukewarm water after meal.

Table No.-2: RASAPANCHAKA OF SIMHANADA GUGGULU ${ }^{4}$

\begin{tabular}{|c|c|c|c|c|c|c|}
\hline S.No. & Drug & Guna (Properties) & Rasa (Taste) & $\begin{array}{l}\text { Vipaka (Taste } \\
\text { conversion } \\
\text { after } \\
\text { digestion) }\end{array}$ & $\begin{array}{l}\text { Virya } \\
\text { (Potency) }\end{array}$ & $\begin{array}{l}\text { Dosha Karma (Effect } \\
\text { on body humors) }\end{array}$ \\
\hline 1. & $\begin{array}{l}\text { Amalaki (Emblica } \\
\text { officinalis) }\end{array}$ & $\begin{array}{l}\text { Guru (heaviness), } \\
\text { Sheeta (coolant) }\end{array}$ & $\begin{array}{l}\text { Panchrasa (all the five } \\
\text { tastes, excluding salt), } \\
\text { sour is dominant }\end{array}$ & $\begin{array}{l}\text { Madhura } \\
\text { (sweet) }\end{array}$ & $\begin{array}{l}\text { Sheeta } \\
\text { (cold) }\end{array}$ & $\begin{array}{l}\text { Tridoshahara } \\
\text { (balances body } \\
\text { humors) }\end{array}$ \\
\hline 2. & $\begin{array}{l}\text { Haritaki } \\
\text { (Terminalia } \\
\text { Chebula) } \\
\end{array}$ & $\begin{array}{l}\text { Laghu (light to } \\
\text { digest), } \\
\text { (drynesss) }\end{array}$ & $\begin{array}{l}\text { Panchrasa (five tastes } \\
\text { except salt, astringent } \\
\text { dominant) }\end{array}$ & $\begin{array}{l}\text { Madhura } \\
\text { (sweet) }\end{array}$ & $\begin{array}{l}\text { Ushna } \\
\text { (hot) }\end{array}$ & $\begin{array}{l}\text { Tridoshahara } \\
\text { (balances body } \\
\text { humors) }\end{array}$ \\
\hline 3. & $\begin{array}{l}\text { Bhibitaki } \\
\text { (Terminalia } \\
\text { Bellirica) }\end{array}$ & $\begin{array}{l}\text { Laghu (light to } \\
\text { digest), } R u k s h a \\
\text { (drynesss) }\end{array}$ & Kashaya (astringent) & $\begin{array}{l}\text { Madhura } \\
\text { (sweet) }\end{array}$ & $\begin{array}{l}\text { Ushna } \\
\text { (hot) }\end{array}$ & $\begin{array}{l}\text { Tridoshahara } \\
\text { (balances } \\
\text { humors) }\end{array}$ \\
\hline 4. & $\begin{array}{l}\text { Shuddha Guggulu } \\
\text { (Purified } \\
\text { Commiphora } \\
\text { Mukul) }\end{array}$ & $\begin{array}{l}\text { Tikta (bitter), Katu } \\
\text { (pungent) }\end{array}$ & $\begin{array}{l}\text { Laghu (light to digest), } \\
\text { Ruksha (dryness), } \\
\text { Vishada (clears channels), } \\
\text { Sookshma (minute), Sara } \\
\text { (brings about movement) }\end{array}$ & Katu (pungent) & $\begin{array}{l}\text { Ushna } \\
\text { (hot) }\end{array}$ & $\begin{array}{l}\text { Tridoshahara } \\
\text { (balances } \\
\text { humors) }\end{array}$ \\
\hline 5. & $\begin{array}{l}\text { Eranda (Ricinus } \\
\text { communis) }\end{array}$ & $\begin{array}{l}\text { Snighdha } \\
\text { (unctuous), } \\
\text { Shushka (minute), } \\
\text { Teekshna } \\
\text { (piercing) }\end{array}$ & $\begin{array}{l}\text { Madhura (sweet), Katu } \\
\text { (pungent), } \\
\text { (astringent) }\end{array}$ & Madhura & $\begin{array}{l}\text { Ushna } \\
\text { (hot) }\end{array}$ & $\begin{array}{l}\text { Kaphavatashamaka } \\
\text { (balances Vata and } \\
\text { Kapha) }\end{array}$ \\
\hline
\end{tabular}

DISCUSSION $^{5,6,7,8,9,10}$

Ama Dosha and vitiated Vata are main causative factors in the pathogenesis of Amavata. Each ingredient of Simhanada Guggulu alleviates Ama and Vata Dosha in the body. Triphala consist valuable 
Mishra Meenu et.al. Vivid action of simhanada guggulu in the management of amavata (rheumatoid arthritis): a review.

phytochemicals such as tannin, alkaloid quinone, flavonoids, phenol - gallic acid, ascorbic acid, hydrolysable tannin chebulinic acid, epicatechin, soluble sugar, ellagic acid, saponins, sterols, diterpenes and terpenoids. So Triphala has antimicrobial, antibacterial, antioxidant and immunomodulatory properties. It is an excellent Rasayan, having rejuvenating components. Eranda Taila (castor oil) posses properties which act as Agnivardhaka (increase in digestive fire), Bhedhaka (penetrate into micro channel), Srotoshodhaka (remove obstruction from the micro channels), balances Vata-Kapha Doshas and eliminate them by purgation. Bitter and pungent tastes present in Guggulu possess the antagonistic properties to that of Ama and Kapha Dosha which are the chief causative factors in this disease. Hot potency of Guggulu alleviates vitiated Vata and does not allow the Ama Dosha to linger at the site of pathogenesis and to create Srotorodha (obstruction). It has also the antagonistic action of cold and dryness properties of Vata (vitiated air). The scraping nature and bitter taste of Guggulu remove the adhered Dosha from the micro channels of body. Thus it controls Ama and Vata together and minimizes the process of pathogenesis. All these above powerful ingredients in combination can give excellent result to control symptoms of Amavata (Rheumatoid Arthritis).

\section{CONCLUSION}

Simhanada Guggulu is Kaphavatahara, Pittavardhaka, Agnideepaka and Amapachaka. The contents of Simhanada Guggulu may act as Disease Modifying Anti Rheumatic Drugs (DMARDS). It has analgesic and anti-inflammatory properties and it modify the immune response to autoantigens. So it is concluded that Simhanada Guggulu can be used as an effective Ayurvedic medicine for Amavata (Rheumatoid Arthritis). This paper is based on classical and modern review of Simhanada Guggulu, there is need of clinical trial of this drug on large number of sample size, which is scope for further research.

Acknowledgement: None

\section{Conflict of Interest: None}

\section{Source of Funding: None}

\section{REFERENCES}

1. H Ralston Stuart, D Penman Ian, et. Al.,Davidson's Principles and Practice of Medicine, 23rd edition 2018, Ch. 24, Page no. 1021.

2. Tripathi Brahmananda, Madhava Nidanam, Vimla-Madhudhara Hindi commentary, Vol-1, Chaukhambha Sanskrit Prakashan Varanasi Reprint, 2014; Ch. 25 verse 1-5, page no. 571.

3. Shastri Kaviraj Ambikadatta, Bhaisajyaratnavali, Vidhyotini Hindi Commentry, Chaukhamba Sanskrit Sansthan, Varanasi $16^{\text {th }}$ edition, Vol-1, 2002, Kasa Chikitsa Prakaran Chp.15, verse 127-129, Page no.855-856.

4. Sharma P.V., Dravyaguna Vigyana, Vol. 2, Chaukhambha Bharti Academy, Varanasi Reprint, 2012, Page no. $239,275,241,298,474 \& 753$.

5. Suman Sen, Sheuli Sen, Shruti Sharma. Triphala: A boon in oral and systemic health. International Journal of Oral and Maxillofacial Diseases, 2016; 1(2): 2427.

6. Himanshu Deswal, Yogender Singh, H.S.Grover, Amit Bhardwaj, Shalu Verma. Curative effect of triphala in medical and dental sciences: a scientific review. Innovare Journal of Health Sciences, 2016; 4(2): 1-4.

7. National Center for Biotechnology Information. PubChem Compound Database; CID-16745534, https://pubchem.ncbi.nlm.nih.gov/comp ound/16745534.

8. Chunekar K.C. Pandey G.S. (2006) Guggulu Varg 38-41. Bhavprakash Nighantu of Bhava Mishra, Chaukhambha Bharti Academy Varanasi; page no. 205. 
Mishra Meenu et.al. Vivid action of simhanada guggulu in the management of amavata (rheumatoid arthritis): a review.

9. Chunekar K.C. Pandey G.S. (2006) How to cite this article: Mishra M, Sharma C, Taila Varga, Bhavprakash Nighantu of Bhava Mishra, Chaukhambha Bharti Academy Varanasi; page no. 786.

10. Dr. A K Nadkarni- Indian Materia Medica Volume 1- page no. 1065. Sharma S et.al. Vivid action of simhanada guggulu in the management of amavata (rheumatoid arthritis): a review. Int $J$ Health Sci Res. 2021; 11(6): 126-129. DOI: https://doi.org/10.52403/ijhsr.20210617 